
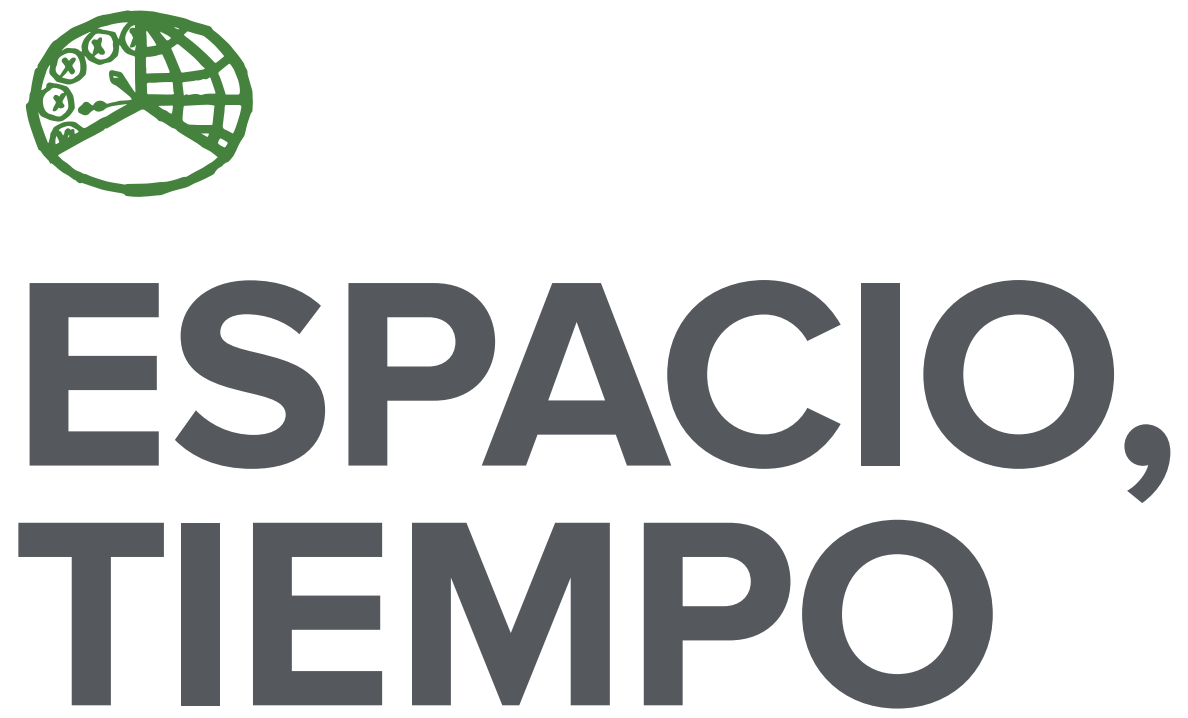

AÑO 2021

ISSN 1130-2968

E-ISSN 2340-146X
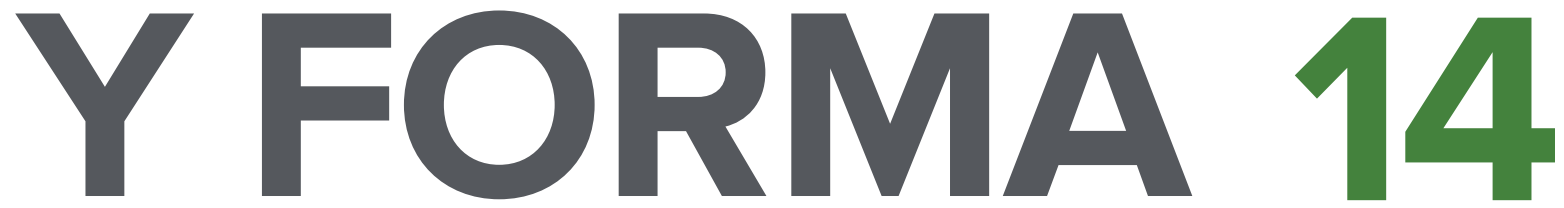

SERIE VI GEOGRAFİA

REVISTA DE LA FACULTAD DE GEOGRAFÍA E HISTORIA 


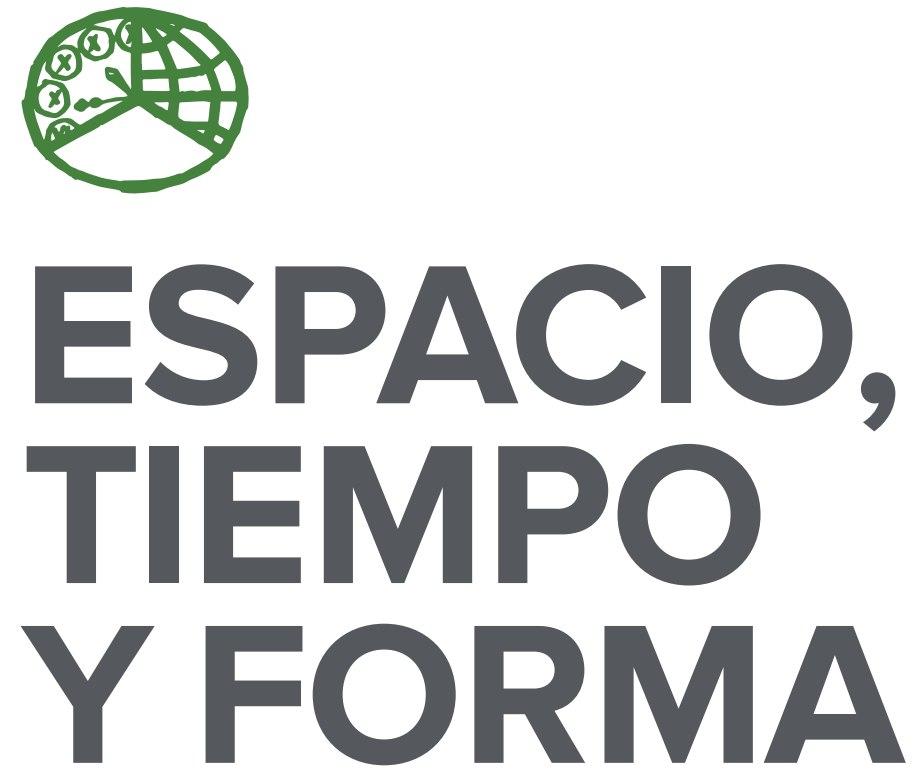

AÑO 2021

ISSN 1130-2968

E-ISSN 2340-146X

SERIE VI GEOGRAFÍA

REVISTA DE LA FACULTAD DE GEOGRAFİA E HISTORIA

DOI: https://doi.org/10.5944/etfvi.14.2021

\section{UחED}

UNIVERSIDAD NACIONAL DE EDUCACIÓN A DISTANCIA 
La revista Espacio, Tiempo y Forma (siglas recomendadas: ETF), de la Facultad de Geografía e Historia de la UNED, que inició su publicación el año 1988, está organizada de la siguiente forma:

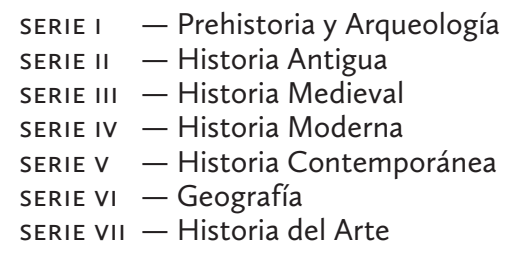

Excepcionalmente, algunos volúmenes del año 1988 atienden a la siguiente numeración:

$$
\begin{aligned}
& \mathrm{N}^{\circ} 1 \text { - Historia Contemporánea } \\
& \mathrm{N}^{\circ} 2 \text { - Historia del Arte } \\
& \mathrm{N}^{\circ} 3 \text { - Geografía } \\
& \mathrm{N} .^{\circ} 4 \text { - Historia Moderna }
\end{aligned}
$$

ETF no se solidariza necesariamente con las opiniones expresadas por los autores.

\author{
UNIVERSIDAD NACIONAL DE EDUCACIÓN A DISTANCIA \\ Madrid, 2020 \\ SERIE VI - GEOGRAFÍA N. ${ }^{\circ} 14,2021$ \\ ISSN 1130-2968 - E-ISSN 2340-146x \\ DEPÓSITO LEGAL \\ $M-21.037-1988$ \\ URL \\ ETF VI · GEOGRAFÍA · http://revistas.uned.es/index.php/ETFVI \\ DISEÑO Y COMPOSICIÓN \\ Carmen Chincoa Gallardo · http://www.laurisilva.net/cch \\ Impreso en España · Printed in Spain
}




\section{ARTÍCULOS · ARTICLES}





\title{
THE TECHNOPOLITICS OF MAPPING \\ DAR ES SALAAM: AN EXAMINATION \\ OF THE TECHNOLOGICAL AND \\ POLITICAL MOTIVATIONS OF THE HUMANITARIAN OPENSTREETMAP TEAM
}

\author{
LA TECNOPOLIITICA DE LA CARTOGRAFÍA \\ DE DAR ES SALAAM: UN EXAMEN DE LAS \\ MOTIVACIONES TECNOLÓGICAS Y POLIITICAS \\ DEL EQUIPO HUMANITARIO OPENSTREETMAP
}

Doug Specht ${ }^{1}$

Recibido: 13/04/2021 - Aceptado: 07/07/2021

DOI: https://doi.org/10.5944/etfvi.14.2021.30644

\begin{abstract}
Mapping has long formed a key part of development work, from recording household surveys, participatory mapping exercises, and PRA projects. Now though the sector is full of new actors- mapping and tech companies as well as NGOs- monitoring through drones and satellite images, alongside employing more traditional methods. Many of these new players were born from NGOs and companies who started as 'crisis mappers'. Short-term 'crisis mapping' projects have become a regular part of humanitarian response following a disaster. The short-term nature of such actions, and the need for stable employment/profits, has led to an increasing trend for the same organizations and companies to either remain on the ground producing maps or to move into new areas as part of a pre-emptive mapping practice, inserting themselves into the wider international development ecosystem. This research, centered on Tanzania, examines how HOTOSM has attempted to pivot towards working as a development organization that creates maps for prevention of crisis, but also wider socio-economic outputs. The research used interviews to explore the interplay between technology and micro/macro politics around the mapping of Dar es Salaam. Examining how HOTOSM its role, and how they position their map-making within the context of Dar es Salaam. Findings suggest that HOTOSM is still underdeveloped as an organization and lacks the maturity to create true participatory models of working.
\end{abstract}

1. University of Westminster, London, UK; d.specht@westminster.ac.uk

ORCID: https://orcid.org/0000-0001-6480-3732 


\section{Keywords}

Participatory mapping; international development; OpenStreetMap; Dar es Salaam.

\section{Resumen}

La creación de mapas ha sido durante mucho tiempo una parte fundamental del trabajo de desarrollo, desde el registro de encuestas de los hogares, los ejercicios de cartografía participativa hasta proyectos de Valoración Rural Participativa (VRP). Ahora el sector está lleno de nuevos actores - empresas de cartografía y tecnología. así como Organizaciones No Gubernamentales, que realizan el seguimiento mediante drones e imágenes de satélite, junto con el empleo de métodos más tradicionales. Muchos de estos nuevos actores nacieron de ONGs y compañías que se iniciaron como 'cartógrafos de crisis'. Los proyectos de 'cartografía de crisis' a corto plazo se han convertido en una parte habitual de la respuesta humanitaria tras una catástrofe. La naturaleza a corto plazo de estas acciones, y la necesidad de obtener un empleo o beneficios estables, ha llevado a una tendencia creciente para que las mismas organizaciones y empresas permanezcan sobre el terreno elaborando mapas o se desplacen a otras zonas como parte de una práctica cartográfica preventiva, insertándose en el ecosistema más amplio del desarrollo internacional. Esta investigación, centrada en Tanzania, examina como HOTOSM ha intentado hacer un giro para trabajar como una organización de desarrollo que crea mapas para la prevención de crisis, pero también resultados socio-económicos más amplios. La investigación utilizó entrevistas para explorar la interacción entre la tecnología y la micro/macro política en torno a la cartografía de Dar es Salaam. Se examinó como HOTOSM desempeña su papel, y como se posiciona en la elaboración de mapas en el contexto de Dar es Salaam. Los hallazgos sugieren que HOTOSM sigue estando poco desarrollada como organización y carece de la madurez necesaria para crear verdaderos modelos de trabajo participativos.

Palabras claves

Mapeo participativo; desarrollo internacional; OpenStreetMap; Dar es Salaam. 


\section{INTRODUCTION}

The last ten years have seen massive growth in digital humanitarianism. Following the earthquake in Haiti in 20I0, more and more NGOs, companies, and projects have sought to use digital tools to aid in both humanitarian efforts and longer-term development work (Hunt and Specht, 20I9). The sector has increasingly sought digital-technocratic solutions for everything from monitoring health (Mesmar et al., 2016), distributing aid (Crooks and Wise, 2013), providing water sanitation (Gopal et al., 2009), or protecting forests (Lee, 2003). While these projects have demonstrated that the internet, digital tools, and data can indeed be harnessed to challenge entrenched economic, cultural and political interests, it remains that it is not a utopian space that allows us to automatically transcend most of the real and place-based constraints that we face (Graham, 2013). Few would argue that uneven development disappears as a result of new technologies and there are real dangers that new and old digital divides will not only trace but also further deepen existing social divides (Adams and Jansson, 20I2; Kleine et al., 20I4).

One such organization to join the growing number of NGOs and private companies looking to harness geographic data for development and humanitarian purposes is the Humanitarian OpenStreetMap Team. The Humanitarian OpenStreetMap Team, affectionately known as HOT, was one of the organizations that emerged during the rise of digital humanitarianism that followed the 2oro Haiti Earthquake. Building on the OpenStreetMap infrastructure, HOT began to develop a platform that allowed for the quick mobilization of volunteers to map areas of the world that we're facing crisis. They saw deployment in numerous natural disasters, including following Typhoon Haiyan in 2013 and the Nepal earthquake in 2015. The organization continued to grow, and so too did its mission. No longer was HOT just interested in moments of crisis, they began to move towards more long-term development and crisis prevention tasks - work that they see as being fulfilled through ensuring places and people are well mapped. The organization is now engaged in I,033 mapping projects around the world and engages tens of thousands of remote mappers (HOT, 20I8). This growing remint of work now centers around the assertion that all people should be mapped on a global scale by HOT, not just in times of acute emergency (Radford, 20I9).

This paper seeks to examine, through the use of qualitative interviews and document analysis, how HOT operates in Dar es Salaam, Tanzania. This paper explores how HOT is envisioned both inside and outside the organization and looks at the way in which data is collected, used, and discussed by members of the HOT team in relation to their work in Tanzania. The aim here is to ascertain the extent to which HOT might have developed a true participatory model in Dar es Salaam (HOT, 20I8) that avoids the theoretical pitfalls of such data and cartographic-driven work.

Dar es Salaam is one of the fastest-growing cities in Africa, with an annual population growth of $5.7 \%$. Urbanization is largely unplanned, and $70 \%$ of city residents live in informal settlements. The pace of this growth has already stretched the limited capacities of the city to accommodate the needs of its population, or to keep statistics and data that might inform further growth patterns. And despite being early adopters of a National Spatial Data Infrastructure (NSDI), which 
organizations such as UNGGIM point to as being key for development, the city, and wider Tanzania has not to date been able to fully implement spatial data in their planning. The information that is available is scattered across many agencies, some of whom are reluctant to share data. Geospatial data for the city is presently managed by a) PMO-RALG, the Prime Minister's Office - Regional Administration and Local Government, b) Ministry of Lands - Mapping and Survey Division, c) National Bureau of Statistics, d). and other government departments, such as the PMO - Disaster Management, which manages flooding data.

The digital development work undertaken in Dar es Salaam by HOT manifests in drawing together some of this data and knowledge, along with a more extensive process of participatory mapping practices involving on the ground collection of data and remote mapping through projects such as MissingMaps. This data is used for mapping the city in every more detail using the OpenStreetMap platform, with the aim of ensuring that everyone in the city is mapped (Radford, 2019), and at the same time to produce a rational and scientific space that can be administered by the State for its development. While the majority of HOTs mapping still happens remotely, in Dar es Salaam they also use on the ground staff and volunteers for more specific community projects. HOT now contributes vast amounts of open - freely usable data, to both the Tanzanian government and the wider humanitarian community via the Humanitarian Data Exchange (HDX). Given how data is increasingly relied upon for decision making around the world, and that lagging behind has potentially huge negative effects (Kennedy et al., 20I6) it might be argued that HOT is already fulfilling the role of bringing justice and self-determination to the population of Tanzania (Digital Globe, 2019; Sletto, 2009). However, caution must be taken, and the fast-paced digitalization of the humanitarian/development sector and the changing focus of HOTs work could leave spaces into which longstanding issues around datafication, representation, and mapping can flow.

\section{THEORETICAL BACKGROUND}

While the geospatial community has a unique opportunity to contribute to the development and humanitarian issues (Rekha, 20I6) there are also concerns about the limits of such projects. There are questions around the social and cultural implications of technology transfers, for example, potential uneven gender relations, or unequal power structures (Parker, 2006; Sletto, 2009). These new modes of data production and digital labor also play a role in the increasing capitalization of the humanitarian sector, with questions around profits, exploitation, and philanthropy all coming to the fore (Burns, 20I9). The quality of data produced by masses of volunteers might also be challenged. Although work by Haklay (2008) has noted that OpenStreetMap is very accurate, there remain questions as to whose knowledge is being mapped. There are also concerns that literature on participatory mapping redraws the binaries that define the raison d'être of development - local and global, developed and underdeveloped (Sletto, 2009). 
Sociocultural map scholars have worked hard to expose the inadequate and distorted conception of maps (Edney, 2019). Since the first mappings of the world by cartographers, the same issues have abounded, how to gain access to the right information, how to capture accurately and then convey that information in a way that effectively communicates what that information means so that it might be understood (Edney, 2019). As more and more technology becomes available for the collection and processing of information or knowledge, this can have a profound effect on the information itself and what knowledge is included, and seen as legitimate (Elwood and Leszcyniski, 2013). Coloniality is still the most dominant form for ordering the world, while no longer an explicit political order, the exploitation, domination, and subjugation of people remains (Quijanao, 2007). Maps have long been seen as a tool of the colonial project, tools of the affluent and the powerful, and much has been written about how they have been used in this way (See Specht and Feigenbaum, 2019; Harley, I988). Relying on user-generated content or volunteered geographic information does not automatically alter these uneven colonial geographies (Graham, 20I7), indeed the collection of such information and materials may exacerbate the situation. Anthropologists once seized upon the archival nature of mechanized media, cataloguing and organizing the other through new data. These processes became an important part of the territorializing of the other (Collier, 2016). Even as neogeography and counter-mapping practices became more mainstreaming the last ten years, the issues of power, inequality, and representation have not gone away (Wainwright and Bryan, 2009). Some might argue that the highly technical nature of mapping, which now so often requires a smartphone or high-end computer, also plays into the requirement for Africa to be a source of technology (minerals, etc.) not the beneficiary of their development (Collier, 20I6). Indeed, the process of mapping is a process of codifying knowledge into 'objective', 'scientific' categories that fit within the ideal of Cartography (Quijano, 2007; Edney, 2019).

Despite these concerns, the role of digital mapping and data collection in international development persists and has even grown with the number of privately-owned sensors, not only harnessing Global Positioning Systems (GPS) but also sound-level, light, and accelerometer sensors. Aggregating data from these diverse and plentiful sensors enable new forms of monitoring societal and development phenomena at an unprecedented scale and is seen by many as key to unlocking the development puzzle (Buckingham Shum et al., 20I2). The kind of data collected in this way may seem universal, but in the real world, it is always integrated with supplementary assumptions that render it culture-bound and parochial. This growth in geographic information, while lauded by many as being the answer to development issues, must be placed within the context of the subjectivity of mapping. Mapping is an act of power that creates space. Maps are an interpretation of space that bears the imprint of the world in which it is made. In the words of historian Brain Harley, cartography 'belongs to the terrain of the social world in which it is produced'. In short, 'cartographers manufacture power' (Cited in Potts, 2015: 19). furthermore, a map represents territory according to the knowledge and worldview of its culture and its period. This means that a map may 
be a mathematical rendering of space - but it can't help also being a viewpoint of the world (ibid.).

In moving from being a reactionary project that responded to an acute crisis, HOT has now tied its work to the wider development agenda. In doing so the organization must now contend more than ever with the social implications of technology, including issues of privacy and the digital divide. This paper will now examine the extent to which HOT has become entangled within, or avoided, these issues as they work in Dar es Salaam.

\section{METHODOLOGY}

This research is based on a series of interviews with staff, management, and donors to HOT. The interviews were conducted in Dar es Salaam over the course of a few weeks, allowing for a snapshot in time to be seen. Interviews of a semistructured nature were conducted with management-level staff at HOT, with the option of anonymity to allow for more free-flowing discussion (names are removed in this paper). Ten such interviews were conducted, capturing the full senior staffing at both in-country and international level. Despite this, it was expected, following the work of Moore et al. (20I6) that the HOT management staff would provide little talk of failure, lost data, or power dynamics. To counter this potentially onesided narrative, interviews $(n=9)$ were also conducted with the community mappers themselves. These persons were identified through a snowballing technique starting with contacts formed through the HOT Management team but seeking to reach beyond these points of contact to other community mappers. These nine individuals were identified as key persons, but while representing the majority of the paid (and for the most part permanent) local staff, were only a proportion of those who work on HOT projects in Dar es Salaam. These interviews, also semi-structured in nature, were designed to examine if the mapping supervisors felt that they were as involved in the participatory projects as promised or indeed if they felt the projects were meeting their aims. To complete the cycle of information and understand how information is presented to different groups, interviews were also conducted with other stakeholders and donors $(n=3)$. These interviews, which took place with staff from the World Bank and IREX, both major donors to HOTs work in Dar es Salaam. All interviewees were asked to describe their connection to, or role within HOT, how they envisage the work of HOT within Dar es Salaam, and their view of the wider organisation. Questions were also asked about the community, sense of belonging, processes of data collection and cleaning, and finally what each interviewee saw as the key outputs of HOTs work in the city.

The data from these interviews were transcribed and coded around 35 themes, which themselves were compiled by collating and merging some of the roo plus codes that were created in the first round. The codes were used to draw together network diagrams in Atlas.ti. These diagrams developed following the methods of Popping and Roberts (1997) show where ideas are linked, how different codes, or ideas stated by staff and documentation, influence and inform each other. This 
enabled the examination of discussions around the three key aspects of interest to this paper, the vision for HOT, the process of collecting, and the process of preparing data.

\section{RESULTS}

Analysis elsewhere (see Fonte et al., 20I7; Brovelli et al., 20I9) shows that HOT has made a huge impact on the mapping of Dar es Salaam. Much of the city is indeed now 'on the map', and it is clear they have produced a range of high-quality maps, that demonstrate the upskilling of the community mappers and the GIS staff in Dar es Salaam. These maps are also clearly of use for showing community concerns and exploring the issues around flooding and disaster management. For all of this HOT should indeed be commended. However, the practice of creating, as well as using, maps is a critical site for understanding power relations around knowledge, and how these are contested (Bryan, 20II). To examine whether HOT has avoided the pitfalls of such work in Tanzania as discussed in the theoretical framework, analysis was undertaken around (I) the vision for, and view of HOT, (2) Uses of Data, and (3) Data Processes.

The first areas of analysis are the vision for HOT - what interviewees claim the Humanitarian OpenStreetMap Team is aiming to achieve in Dar es Salaam - and the view of HOT, what those interviewed feels about what HOT is and how well it performs - views which often encapsulated the wider organization. It is worth noting that during the interviews there was a sense that each person had a different idea about what HOT is, and what they should be doing in Tanzania. HOT was described as a 'development organization', a 'humanitarian organization', a 'tech company', a 'mapping company', an 'off-shoot of OSM', a 'social enterprise' as a 'business', among other descriptions. These mired different ways of expressing the work of HOT was a concern to some, but others saw it as a strength.

In the networking of ideas about the vision for HOT, from the 35 codes available, when talking about what HOT should be aiming to achieve in Dar es Salaam the majority of discussion revolved around funding and donors. While uses of data also featured as a code for this analysis, looking more deeply into the quotes it is possible to see that comments related to the vision for HOT and uses of data are also strongly associated with donors, clients outside of Dar es Salaam and funding. When asked about the use of data the Tanzanian respondents frequently suggested the data was for other organizations or government bodies, rather than for $=$ the community themselves. «If the government needs a certain data, you can give them [sic.]» noted Mapping Supervisor I (MSI). In-country Project Manager I (C-PMI) suggested similar when asked about whom they were making the maps for; «It depends on the project,» but when pressed for more stated; «for example, what we're doing right now there's another partner called Deltares who were doing some planning and interventions to flood areas. they're the ones who say what kind of data they need». 


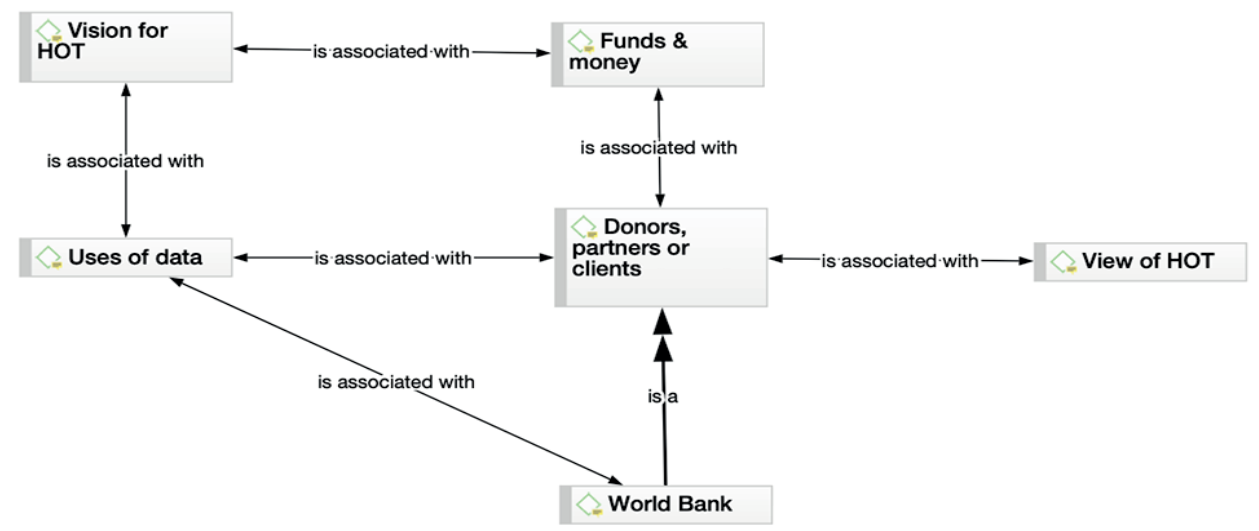

FIGURE IA: VISION FOR HOT - DEVELOPED FROM CODING INTERVIEWS AND DOCUMENTS IN ATLAS.TI

A former employee of HOT, who had worked in Dar es Salaam, also noted that there were some concerns within the local staffing that the way collected data was to be used wasn't always explained; «All that they could tell them was, 'we are collecting it for this reason, and the World Bank intends to use it for this resilience planning and finding better ways to stop your house being flooded» (interview). It follows then, that when the 'uses of data' for the local community were presented in interviews much of this was spoken about in relation to donors, even where the data was intended for use at a very local level in Dar es Salaam

There was though some disconnect between how the donors were expecting data to be used, and how it was actually used. A consultant to the World Bank (WB, interview) noted that two years after HOT first made maps of a Ward in Dar es Salaam, these were still on the wall of the ward leaders office; «the people were using the maps but using the maps in a way that was completely unexpected so it was really that they were saying for example somebodies going to move into the area, they see that the - the house or the plot already has a road so they're like, 'Oh okay you know I can come here because there's already a road'».

The vision for HOT in Dar es Salaam appears through figure ra as being influenced by the donors and external recipients of their data. Staff had reservations about this idea, for example, a senior member of staff from the global management team (I-SMI, interview) challenged the prevailing literature (Radil and Jiao, 2or6; Parker, 2006; Mosse, 200I; Mohan, 2002) on the influence of donors, while also highlighting the complex relationship and power dynamics;

I would say that I want to see the literature because I would question it. After all, truly it's about alignment. We have a giant multinational law firm that's invested in our work because, I think, the pessimistic view would be they want to put a pretty face on something or working with other kinds of large organizations that may have a negative wrap around data security and things like that. But then there are areas where there's a lot of potential for a collaboration where our purposes align. [...] Foundations have a mission just as large corporations do and visions and things like that and they see your work when they give you a grant as fulfilling their mission. This is why they want all the irritating reports back and things like that and the thing that arguably takes away some of your time and there's a big kind of pushback. Also, I think one of the major 
kind of focuses now is on assessing how good is the donor? We're like, «Okay. Money is great in grand but are you making us do more for that? And are you lessening our ability to do our work by giving us that money?

To examine HOT's literature and reports suggest a different story, one in which the data is directly for the use of the community, and donors are rarely mentioned. «The HOT Tanzania team are collecting health data in Dar es Salaam and Mbeya region to improve public health services» (HOT, 2020). «Through these projects HOT aims to use OpenStreetMap to create sophisticated and highly- accurate maps of Dar es Salaam to support the local community» (I-MM, interview).

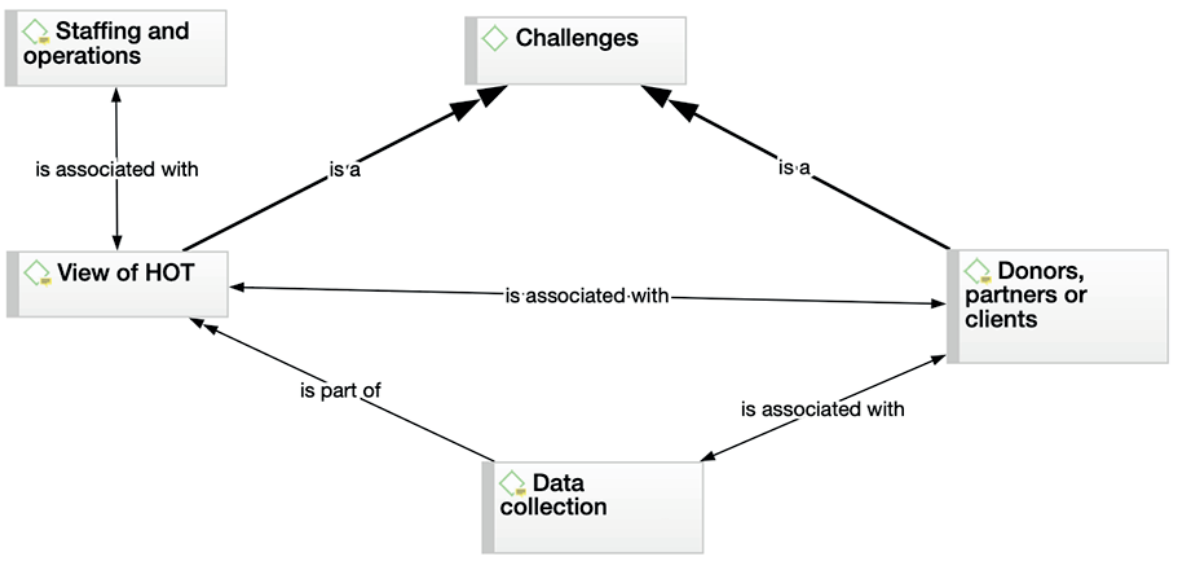

FIGURE 1B: VIEW OF HOT - DEVELOPED FROM CODING INTERVIEWS AND DOCUMENTS IN ATLAS.TI

There are stark differences when looking at the view of HOT, a concept which was more encompassing of the whole organisation than other codings. While both are associated with donors and clients, the view of HOT (figure $\mathrm{Ib}$ ) is more aligned with challenges, data collection, and staffing than with donors. This would imply that the view of HOT (present) is more closely connected to the original aims and objectives of the work in Dar es Salaam and HOTs wider missing to ensure everyone is mapped (Radford, 20I9). While the vision for HOT (potential) is being driven by outside influences. This is seen in the very central position of challenges, sitting between the view of HOT and their Donors. Here the question of what HOT is and where they should be heading in Dar es Salaam was more fraught. One senior member of in-country staff (C-SM2, interview) was very clear about how they saw things,

There's a faction of people who resist becoming a sort of official corporate entity. It is an incorporated company, [inaudible 00:38:51] it's a charitable Corporation in the United States. Some people see that as selling out the principles of community activism and organization, accepting money and resources from the American government. Nobody, least of all me, fools ourselves that the American government gives money away for purely altruistic reasons and some people feel that accepting the penny from the United States government means that you are purely an instrument of the United States soft power and certainly HOT gets a lot of money and support from the US government. 
These sentiments seem to be at odds with those of the SMi mentioned above. The different directions that HOT is being pulled is also highlighted by $\mathrm{I}_{-} \mathrm{SM}_{3}$ (interview), «I think it's a bit of a continuum between organization and community. So, a lot of people talk about that in one breath like HOT is one thing. Like personally that doesn't make sense to me». C-PM3 sees HOT as more of an «activating agency, that their whole premise is around humanitarian data» (interview). What is perhaps of note here is the lack of Tanzanian voices within the vision for HOT. Despite all interviewees being asked a very similar set of questions, nothing from the Tanzanian staff was coded as being about the vision for HOT. This suggests that they did not feel part of that conversation to an extent that they either did not see themselves as contributing to the future vision of the organization as a whole, or at a local level.

There is then a somewhat unclear view as to what HOT is, and should be, doing in Dar es Salaam. To explain this further the use of data by HOT was placed at the center of the analysis. Figure 2 - which shows how interviewees discussed the uses of data by HOT in Dar es Salaam - demonstrates the imbalance between associations of uses for data and the local community compared with the vast range of other uses of data. Uses of data were mentioned considerably less in relation to the local community than relation in discussions about outside users (NGOs and other organizations, Donors, patterned of clients, World Bank) or the vision for HOT itself. This then implies that HOT is more focused on the uses of data that feed either into their vision or that feed into the vision of the donors and other NGOs, as opposed to the needs or desires of the local community. This is not to suggest that this is a conscious aim or that there is a desire of HOT to mislead the local community, but rather a suggestion that HOT as a global entity has been unable to avoid the kind of biases and entanglements created by working with donors on an international scale while trying to conduct locally led projects. Leading to a misalignment between HOTs local and global ambitions.

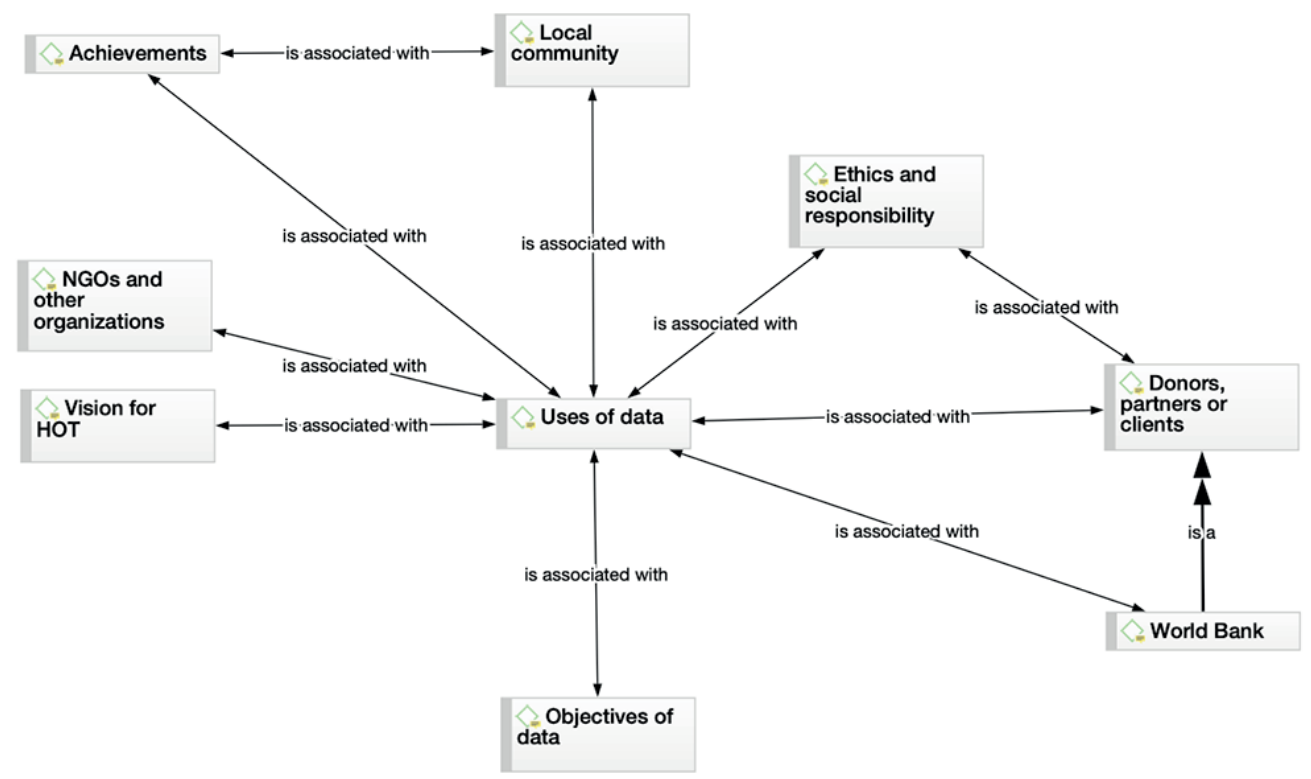

FIGURE 2: USES OF DATA - DEVELOPED FROM CODING INTERVIEWS AND DOCUMENTS IN ATLAS.TI 
These tensions were highlighted by C-MSI (interview) who notes that people are told in the field that «we are going to collect this data and this data will be used.» Local communities have then been frustrated by the lack of action following the mapping of drainage systems, resulting in community mappers having to tell people «Okay, we are not the ones that are going to construct for you. Stop expecting us to go and construct it next week». The mapping implies the data will be used to fix drainage - a local community use of the data, but in reality, the data is used to inform the government who then choose how to allocate their budget, an external (non-community) use of the data. While the outcome might be better drainage and reduced flooding risk (which has been the case) the processing and ownership of data is poorly communicated. This is an issue also found by Mapping Supervisor 2 (C-MS2, interview), «In rural areas [...] it's usual for many people don't understand what we're doing. They expect that the actions, the little actions that are what they want [sic.]».

The question of objectives of data use was raised in all interviews and was framed around questions of cleaning data and looking at how the data moves from being collected by individuals, passed to mapping supervisors, through data collection tools, then cleaned and passed to digitizers who then create map. However, while Dar es Salaam based mapping supervisors reported a disconnect between maps collection and action, as noted above, more managerial level staff denied there could be any data loss or misinterpretation in the flow. One project manager, C-PM2, sums these sentiments thus; «this data belongs to the community and it reflects the collective nature of what communities are saying about the challenges that they face», they go on to explain that issues in the data might be from the community level, «however, you have to keep in mind that just because a community says something we cannot just take it for plain or fact. It gives us a starting point to go into that community and investigate what that problem may be».

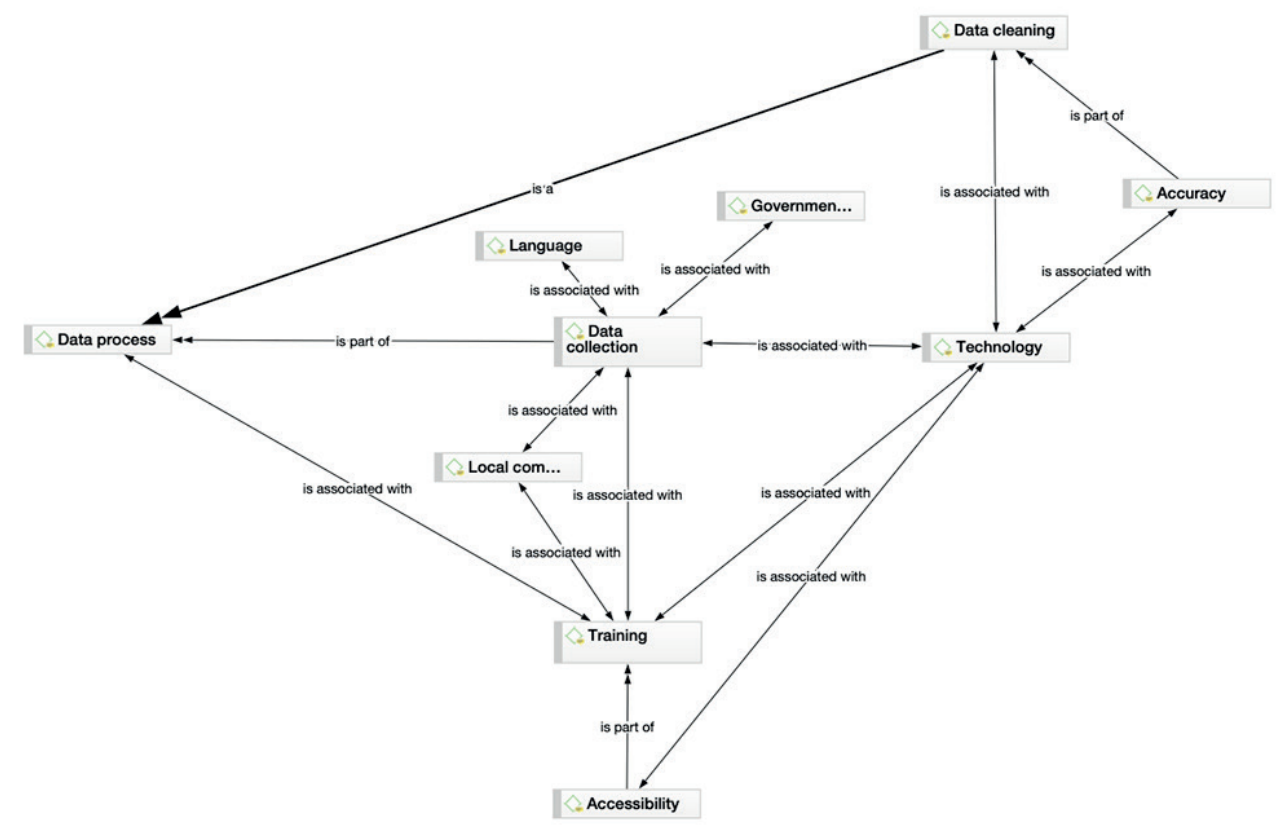

FIGURE 3: DATA PROCESSING - DEVELOPED FROM CODING INTERVIEWS AND DOCUMENTS IN ATLAS.TI 
There are then some contentions about who the data is for and what happens to the data once it is collected. These tensions appear to exist not only between the community and the local HOT team, but also between members of HOT themselves, especially local to global. These contentions are drawn out in figure 3 which shows how this topic has been discussed.

Here we see some previously discussed themes and some new ones that relate more closely to data processing. Donors, NGOs, other outside influences are not directly linked to the data processing. Nor though is the local community or government. There are of course links between the data collection and the process, as there is with the discussion of cleaning. Training is also heavily associated with data processing - understandable given the levels of knowledge required to undertake this work. Looking more closely at how cleaning and processing were discussed it became clear that there are numerous moments at which inaccuracies or bias could creep into the data collected and sorted by HOT. In the data collection process, C-PMI (interview) notes that following the door to do the collection of data, «we came back and filled all that data we had collected since the community is the ones who were collecting sometimes, they might make mistakes because they are in the survey, there are places that we have to type, not selecting. So, we have to sit and clean all data that we have collected so far and produce maps». While this mostly involves the correcting of spellings there is a risk of additional ideological changes being made at this stage. A digitizer of incoming data and GIS expert (C-GISI, interview) suggests that even following this process not all the data is immediately usable, «some data can be maybe like a technical problem, maybe someone filled the information which can lead to a block of something like that».

Discussing some of the missing or 'incorrect' data, in-country Senior Manager 3 (C-SM3, interview) suggests the issue is minimal, «l can talk of the 35,000 points we collected we only had like 50 points that never had location». C-PM2 though implies this is a rather bigger job than just adding a few location points;

\footnotetext{
The data cleaner is generally an intern or a student who kind of works a few hours a week, has an office pay rate, and so is doing kind of quite monotonous work in a way. But a very integral part of the work that we do is by having a clean data set. And so, I think it's because they're not involved in that process. After all, by the time the data is clean enough to start playing around with, the analyst, his time is worth a lot more, we need to think about the time and cost. [...] this field is very new and we're still kind of learning and making things up as we go and trying to see how can we be the most effective and bringing in different actors to do the best job that we can.
}

$\mathrm{C}-\mathrm{PM} 2$ here raises some interesting points, it appears that the mapper supervisors are perhaps unaware of the level of data cleaning that is taking place - enough for regular employment. Furthermore, those undertaking the cleaning are disconnected from the projects and outcomes. This has to potential for many factors to creep into the datasets. In terms of other processing of data, little more was said beyond the process of cleaning, only one interviewee expressed that the choice of what to put on each map was also part of the process, C-MSI (interview) states «okay, they're collecting data from the site and then the data is cleaned.» And then after 
data cleaning, okay, we have already had data now. Manipulating that data, okay, we need some maps maybe to show something that you have data, and then that process of changing that data and representing it in maps».

\section{DISCUSSION}

A great many challenges face HOT as they carry out their work in Dar es Salaam. There are issues of vision and view of the organization itself - at both local and global scales - with seemingly no clear direction or consensus even within the Tanzania team as to what HOT should be seeking to achieve. This is coupled with being pulled in different directions by donors and local communities. With the local community being left a little in the dark compared with other partners. There are also issues of how data is collected, sorted, cleaned, processed, and mapped - again, members of HOT from different stages in the process appear to have different ideas about what the data is being used for, who the data is for, and the levels to which it is being cleaned and reorganized - potentially by people who are quite outside the project.

All these challenges have been mapped into figure 4. This diagram shows the complexity of the narratives and environment within which HOT is working in Dar es Salaam. Some of these challenges were predicted in the literature, for example, the diverging viewpoints on how data should be used (Kim, I998); whose knowledge should be included (Kyem, 200I; Chambers et al., I979); the influence of donors (Mohan, 2002; Mosse, 200I) and the affordances of technology (Hutchby, 200I) Others, such as how HOT views its past and future have emerged directly from the research itself.

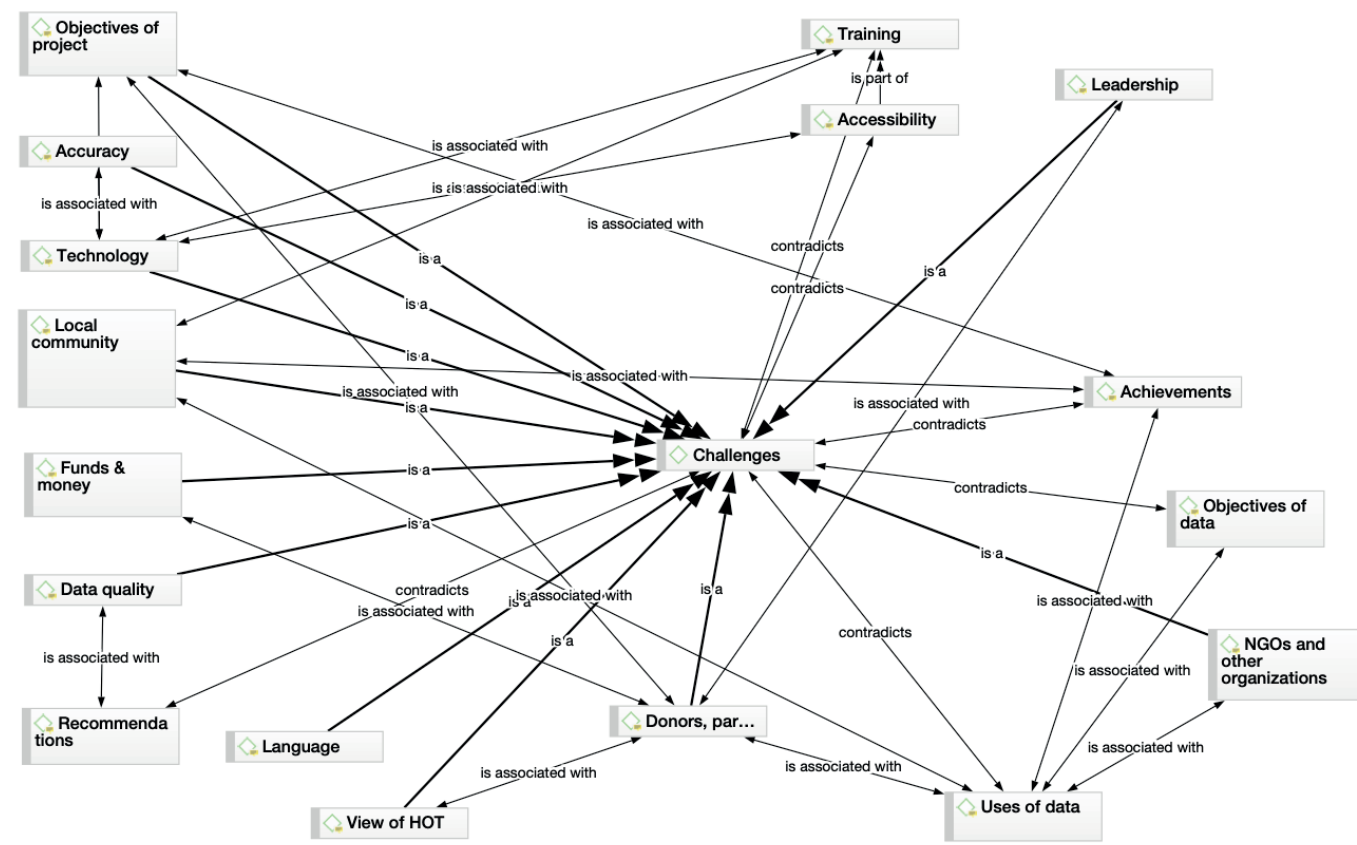


HOT has vastly improved the maps of Dar es Salaam. As executive director Tylor Radford (2019) notes, when HOT began working much of the map of Dar was blank, the HOT volunteers have added everything from street names to health clinics, to tag data on the kind of care given at each medical facility. It is also clear that these maps and the vast amounts of data being produced have indeed been mobilized in aid of a great many life benefiting projects, raising the profile of several issues in the city, including waste management, flood risks, and access to healthcare (ibid.). HOT has also overseen the training and development of community mappers, GIS digitizers, and data analysis, as well as teaching people how to collect geospatial data about the city and providing 'essential' map reading skills beyond the boundaries of its projects (Sieber, 2006).

These accomplishments then should be lauded, and the purpose of this paper is not to take away from said achievements. It is though clear there are frictions and some significant theoretical issues at play. In a discussion on the codification of knowledge, such frictions must abound; knowledge has certain properties, things it can do to the world, how it is represented, and codifying it will change, mutate, affect or remove these properties and that must be examined closely (O'Hara, 2004). It is then important that an attempt is undertaken to see how inclusion/ participation takes place within these HOT projects, as this is something they position as one of the key parts of their work and is certainly one of the aspects they 'sell' to donors. As a consultant to the World Bank puts it, «it's the focus on participatory mapping and the integration with the local ecosystem, that's what was extremely [appealing]» (interview).

Tyler Radford, Executive Director at HOT, suggests that «by having local contributor, we $[\mathrm{HOT}]$ believe that we can build a more representative map of the world» (Radford, 2019). There is through a risk that in pivoting from being a humanitarian organization, to one that is focused primarily on ensuring everyone is on a map through local and global participatory mapping exercises, that HOT is forcing many peoples into in imperial logic under the no-win situation often referred to as Map or Be Mapped (Paglen, 2008). HOT, along with the wider humanitarian and development sector is increasingly relying upon and giving value to data and mapping (Kennedy et al., 20I6), but cartography is not only poor at describing the qualities of the relationships of everyday life, it also forms power and has traditionally been used as an instrument of both colonialism as well as the contemporary geopolitical ordering of the world (Specht and Feigenbaum, 20I9; Paglen, 2008). It has already been seen in the analysis of the interviews that donors and the vision for HOT have more influence over data collection than the local population. This chimes with the work of Sieber (2006) who has noted that the data which is important to social scientists may well have little significance to community groups - an idea summarised wittily by Neff (2013:II9), «data is only data in the eye of the stakeholder». Radford (2019) also goes on to contradict himself somewhat, suggesting that «the more global our [HOTs] team becomes, the better maps we produce», not the words of a locally focused project.

The processes through which HOT works with the community in Dar es Salaam are designed to include as many people as possible, or at least this is what 
they state; «we work together to provide map data which revolutionizes disaster management, reduces risks, and contributes to the achievement of the Sustainable Development Goals» (HOT, 2020). The aim is to invite community engagement and participation (Parker, 2006), more than this, HOT aims to drill into the local, or even the hyperlocal; «training local people to collect the data for themselves» (C-SM3, interview); «creating the map in a detailed local way» (I-SM3, interview). This uncritical invocating of 'the local' though can play a role in recreating binaries between the mapper and the mapped. Those who are active (mappers) and those who are passive (the mapped). Developing this dichotomy can have disastrous effects (Hart, 200I) and local knowledge can be transformed into a tool that serves the needs of the colonizer (Kitchin et al., 2009).

Furthermore, HOT does not include much of the community. While individuals are trained to go out into the community to collect data, these a few in number compared to the population. The mere act of answering a survey or having your house mapped does not constitute participation, even if it might result in representation. Indeed, the barriers to working with HOT are high, while it is suggested that they are «recruiting people from the communities», as C-PM notes, they are «mostly [...] using university students to do these activities» (interview). As Edwards (2015) saw in their research, as we further examine the way technologies are being used in citizen engagement the more we see that it the tech-savvy that are getting involved, potentially at the expense of other communities. There are also significant human/ socio-cultural factors that continue to be barriers to participation in such projects, gender, self-confidence, and background for example (Verplanke et al., 20I6). While donors, via the reports provided by HOT, were under the impression that when selecting mappers and fieldworkers «technical skills, literacy, and gender balance were all factors of consideration» (HOT, 20I8), the story on the ground appeared to be rather different, with I-SMI (interview) noting on a visit to Dar es Salaam that;

\footnotetext{
I came in and saw and went and visited and did some mapping with them locally, and they were giving out just a basic semi-structured interview survey. And there's some very clear-, they take a geo-point, ask these questions about maternal child healthcare. They didn't ask the gender of the respondent. So, there are some obvious survey design issues and limitations there. But because I have that background and I've done community and participatory based kind of projects and research and things like that, I'm thinking about those things and I think just providing one more I, that's not quite so deeply embedded in what's happening.
}

These concerns mirror those of Radil and Jiao (2016) who have noted that participants in PGIS projects are generally 'middle class, affluent' community members and that this in itself can lead to diminished inclusion of people with different identities. This will also affect how the information gathered is then cleaned and codified - There were already marked differences in opinion on how much cleaning was being done to the data, with the mapping supervisors suggesting that the data collected was very high quality, while staff from further up the chain suggesting that so much work was required to clean the data. These differences might raise concerns over how much those on the ground really know 
about the data being collected. Of course, data will also represent and reflect social relations and power, this can hardly be avoided, however, the approach of HOT to employing technology wholesale, with the idea that more data is better suggests an epistemological position that is not fully embracing of the participatory model. As C-SM2 (interview) stated rather gleefully in relation to data collection, «the robot overlords are going to take care of that. machine learning is going to take care of digitization in a couple of years. So, what's left for us? that leaves some room for us to act. As for the implementation that's-, when the computers can do that, then we'll have other problems or other opportunities»

This highlights the tensions between community mapping as emancipatory politics versus reproducing power relations (Parker, 2006). HOT may have found themselves entangled in the idea that anyone can make a self-representation if they want (regardless of means) and that this in and of itself opens the public discourse around issues (Kidd, 20I6). A romanticized notion of 'the local', which might be seen as rising from much post-development literature, also provide HOT's project managers with a sense that 'local' places are homogenized or are sites that might constitute grassroots action (Hart, 200I). In Dar es Salaam, HOT also began to fetishize the 'Hyper-local' as being a sign that they were achieving even more in terms of participation while changing little of their actions - potentially embracing a revisionist neoliberal approach to development, masked by the fetishized role of individualized data (Jordan, 2015; Hart, 200I; Adinani, 2018).

The literature makes clear that the act of mapping somebody does not equate with representation or participation, and might even have negative consequences. Mapping as a spatial practice works in relation to neoliberalism, and the maps created by HOT in Dar es Salaam, also serve this end, allowing for increased government rationality and creating recognizable patterns into which policy and economic reform can be placed (Bryan, 20II). Mapping also creates the possibility of other neoliberal moves, such as the creation of new property regimes, which have very different political agendas to the work of HOT or needs of the community. After all, space is not a reflection of society, it is society. It is produced by human action, and this is always expressed and performed in the interests of the dominant class (Castells, I983). HOT, as a global entity, was formed on a utopian notion that maps and data could save lives and readdress imbalances in the world, and there is certainly an argument that this is possible - Scott and Rajabifard (2015) for example point to the successes of using geospatial information in achieving the Sustainable Development Goals. HOT thought is far from utopian, but rather for all the good they have achieved in Dar es Salaam, they have brought an equal and opposite set of issues to the city, these are borne of three interwoven problems; firstly, institutional organization, secondly a misunderstanding of what HOT is for, leading to them pushing into a development sector without theoretical caution. And finally, a lack of acknowledgment of the construction of space and power through mapping practices.

The lived experience of people is difficult to translate into GIS technology and maps and to suggest that this might be happening in Dar es Salaam would be a stretch. Community mapping, and mapping the community should be seen as different 
practices here, and HOT engages more in the latter, creating maps of people and locations, not those that encapsulate social and cultural meanings or relationships of power (Parker, 2006). HOT has utilized a range of technologies to create vastly improved maps of Dar es Salaam, and these can be used for all kinds of civic and capitalist projects by those who can access them. However, in terms of the inclusion of knowledge and the local community, they have a long way to go, and the layers of technology - which now increasingly involves drones and machine learning means they might be moving further away from the inclusion of the 'local'.

While HOT still broadly describes itself as a humanitarian organization, the work they are undertaking in Dar es Salaam is undoubtedly closer to development work, and in the interviews, HOT was referred to as a development organization a number of times (C-SM3, C-MSI, I-SMI, WB). The projects are for the most part headed by white foreigners, with the local population presented as both backward and innovative (Said, I985; Kidd, 2016). Into this technology is pushed, seen as a driver of not just improved health and waterways, but also economic growth. Vast amounts of data are now collected about the local population, and while made public, is generally only useable by small parts of the population. Information has always been used for both exploitation as well as liberation, and HOTs sense that only the latter will come from data collected in Dar es Salaam is naïve at best information politics is always transformed onto other struggles and data becomes a tool and weapon in times of political antagonism (Jordan, 2015). In this respect then the tools of development being used and implemented by HOT in Dar es Salaam should be viewed as what Escobar (1992) termed Junus-faced. No amount of mapping will solve social issues, especially those outside the Euclidean space. And while the push for more geographic data to aid in development should perhaps be encouraged, there requires more critical reflection on development issues by those undertaking the task, else this collection of data can become nothing more than the creation of abnormalities; the poor, the malnourished, the illiterate, pregnant women, with the implication that these then need treatment, seeking to eradicate all problems (Escobar, I992).

The use of OpenStreetMap (OSM) and other open source and free technologies by HOT were often cited in the interviews as being an example of how HOT is avoiding such issues around technological development. The openness is seen as a fix-all. While these open technologies do enable them to reach a great many people and to use people from all across the world to map and develop projects, but this does not automatically mean this is better, and may indeed work to reinforce and amplify inequalities (Edwards, 2015). Without a deeper understanding of the entanglements between data and power, the creators of OSM may have created a false flag of representation, imbued with ideology and colonialism - in using this as their principal tool HOT too becomes unchallenging a part of this process, these issues of neo-coloniality are not only seen in the way in which mapping tools are selected and used without much questioning. This lack of challenge was noted in the interviews, in which all those spoken too had very positive opinions about OSM and its use for the mapping of Dar es Salaam; seeing it as a community mapping project in the sense that the mapping is carried out by volunteers from 
the community around the world, with no acknowledgment that this process still forces these mappings into normative symbology and design, which by their nature excludes other ways of looking at the world.

HOTs institutional issues of high turnover of staff, colonial power structures, and a lack of focus and coherent vision, make a critical reflection on the process of mapping a near impossibility for the organization. But this philosophical thought around maps is of huge importance as it dictates the way we think about and produces maps (Kitchin et al., 2009). Further, it influences how we think about measuring the world, the role of ethics, ideology, and aesthetics, fundamental aspects of mapping (ibid.). HOT like many mapping advocates see the map as a way of enabling people to be counted, to help make 'better' decisions using more quantitative measures, to promote data transparency and awareness. But this notion of 'doing good' is tied heavily to the idea that information is a means of empowerment, and lacks the nuances and theories that point to mapping and data as having been used for unwriting indigenous occupations of places, shaping public opinion in times of crisis and war, and creating expectations for the proper ordering of the social and the natural. Maps put things and people in their place. Not only do they order the material world and make us visualize the where, but through their rhetorical power, they also simultaneously obscure the why. Most maps are mute about the social context and consequences of their existence (Sletto, 2009: 445). It is clear that we need a new paradigm for data and mapping for development and social change. It seems that HOT though is not the organization to shift this paradigm in Dar es Salaam, but rather one that seems to enforce it. Until they as an organization fix their internal struggle, the specters of dependency, neo-colonialism, and exploitative capitalism will continue to seep in through the gaps, undermining what is, by other measures, impressive work.

\section{CONCLUSION}

This leaves HOT in a difficult position in Dar es Salaam, despite its best intentions - and there is no reason to suspect they are not genuine good intentions - they have become embroiled in neo-colonial development tendencies. This has occurred through their selection of technology, the implementation of technology, and the decisions taken which means that participation is more often than not a low-level role that involves the giving of data, rather than using it. Furthermore, HOT's work in Dar es Salaam may have slipped into a kind of 'data fundamentalism' in which the pursuit of data has become fetishized beyond everything else (Crawford, 2013). The notion that the data will help, and the use of technology bringing everyone to the table in an equal way is to pursue hegemony through technological mastery (Feenberg, I99I) and treats knowledge as property, to be collected and extracted, sorted and refined on behalf of those who own it - the colonial imagery here is no accident (Quijano, 2007; Couldry and Mejias, 2019).

There is a mismatch between the published aims of HOT in Dar es Salaam and what their staff, volunteers, and locals believe they should be doing. This leads to 
projects and actions across the city, some of which appear disjointed, and others which are implemented without wider consideration. Many of these develop from chasing new technology and new donor money, but with less consideration of longer-term impacts on the local population. Ultimately HOT lacks focus in Dar es Salaam and continues working in a reactionary fashion, as their early crisis mapping required. As they have moved to be more of development focused organization this lack of focus has led to them recreating many of the issues of development that have long been critiqued, and in some of their work in Tanzania have turned back the clock, recreating levels of dependency and coloniality that the development sector has long been struggling to shake. 


\section{REFERENCES}

AdAMS, P.C. \& JANSSON, A. (20I2). Communication geography: a bridge between disciplines. Communication Theory, 22, 299-318. https://doi.org/IO.IIII/j.I468-2885.20I2.0I406.x

AdinANi, H. (2018). Newly-revealed Shina boundaries offer unprecedented hyperlocal data for decisionmakers. Medium. Available from: https://medium.com/data-zetu/newly-revealed-shina-boundaries-offer-unprecedentedhyperlocal-data-for-decisionmakers-grazbceo4aze

Brovelli, M., Ilie, C. M., \& CoetzeE, S. (20I9). Openness and community geospatial science for monitoring SDGs - an example from Tanzania. Sustainable Development Goals Connectivity Dilemma: Land and Geospatial Information for Urban and Rural Resilience, 313-324. https://doi.org/IO.I20I/9780429290626-20

BRYAN, J. (2OII). Walking the line: participatory mapping, indigenous rights, and neoliberalism. Geoforum, 42 (I), 40-50. https://doi.org/IO.IOI6/j.geoforum.20I0.09.00I

Shum, S. B., Aberer, K., Schmidt, A., Bishop, S., Lukowicz, P., Anderson, S., ... \& Helbing, D. (20I2). Towards a global participatory platform: democratising open data, complexity science and collective intelligence. European Physical Journal Special Topics, 2 I4 (I), I09-I52. https://doi.org/IO.II40/epjst/e20I2-0I690-3

Burns, R. (20I9). New frontiers of philanthro-capitalism: Digital technologies and humanitarianism. Antipode, 5 I(4), IIOI-II22. https://doi.org/IO.IIII/anti.I2534

CASTELls, M. (1983). The city and the grassroots: a cross-cultural theory of urban social movements (No. 7). University of California Press.

Chambers, R., Howes, M., Belsaha, D., Richards, D., Swift, J., \& O’Keefe, L. (I979). Rural development: whose knowledge counts. IDS Bulletin, Io(2).

Collier, D. (20I6). Repainting the Walls of Lunda: Information Colonialism and Angolan Art. University of Minnesota Press. https://doi.org/I0.5749/minnesota/9780816694440.00I.00oI

Couldry, N., \& MEjIAs, U. A. (20I9). Data colonialism: Rethinking big data's relation to the contemporary subject. Television \& New Media, 20 (4), 336-349.

https://doi.org/IO.II77/I5274764I8796632

Crawford, K. (2013). The hidden biases in big data. Harvard Law Review, I

Crooks, A.T. \& Wise, S. (2013). GIS and agent-based models for humanitarian assistance. Computers, Environment and Urban Systems, 4I, IOO-III. https://doi.org/IO.IOI6/j.compenvurbsys.2013.05.003

Digital Globe (n.d.). Transforming Our World: Geospatial Information - Key to Achieving the 2030 Agenda for Sustainable Development. Geospatial Media and Communications.

EDNEy, M.H. (2019). Cartography: the ideal and its history. University of Chicago Press. https://doi.org/I0.7208/chicago/9780226605715.00I.000I

EDWARDS, D. (2015). Is tech-enabled citizen-engagement a game changer for development. Hivos People Unlimited, 20 March.

https://www.makingallvoicescount.org/blog/is-tech-enabled-citizen-engagement-a-gamechanger-for-development/

Elwood, S. \& LeszCZYNSKi, A. (2013). New spatial media, new knowledge politics. Transactions of the Institute of British Geographers, 38 (4), 544-559. 
https://doi.org/IO.IIII/j.I475-566I.20I2.00543.x

EscoBAR, A. (1992). Imagining a post-development era: critical thought, development and social movements. Social Text, 3I/32, 20-56.

https://doi.org/I0.2307/4662I7

Feenberg, A. (199i). Critical theory of technology. Oxford University Press.

Fonte, C. C., Minghini, M., Patriarca, J., Antoniou, V., See, L., \& Skopeliti, A. (20i7). Generating up-to-date and detailed land use and land cover maps using OpenStreetMap and GlobeLand30. ISPRS International Journal of Geo-Information, 6(4), I25.

https://doi.org/I0.3390/ijgi6040I25

Gopal, S., Sarkar, R., Banda, K., Govindarajan, J., Harijan, B. B., Jeyakumar, M. B., ... \& Balraj, V (2009). Study of water supply \& sanitation practices in India using geographic information systems: some design \& other considerations in a village setting. Indian Journal of Medical Research, I29 (3), 233-24I.

Graham, M. (2013). Geography/internet: ethereal alternate dimensions of cyberspace or grounded augmented realities. The Geographical Journal, I79 (2), I77-I82.

https://doi.org/IO.IIII/geoj.I2009

Haklay, M., Singleton, A. \& Parker, C. (2008). Web mapping 2.0: The neogeography of the

GeoWeb. Geography Compass, 2 (6), 20II-2039. https://doi.org/I0.IIII/j.I749-8I98.2008.00167.x

HARLEY, J.B. (I988). Silences and secrecy: the hidden agenda of cartography in early modern Europe. Imago mundi, 40(I), 57-76. https://doi.org/I0.1080/03085698808592639

Hart, G. (200I). Development critiques in the I99os: culs de sac and promising paths. Progress in Human Geography, 25 (4), 649-658.

https://doi.org/IO.IIgI/0309I320I682689002

HOT. (2018). Annual Report.

https://www.hotosm.org/downloads/20I8-Annual-Report.pdf

HOT. (2020). What we do. Humanitarian OpenStreetMap Team.

https://www.hotosm.org/what-we-do

Hunt, A., \& Specht, D. (2019). Crowdsourced mapping in crisis zones: collaboration, organisation and impact. Journal of International Humanitarian Action, 4(I), I-II. https://doi.org/I0.II86/54IOI8-0I8-0048-I

Hutchiy, I. (200I). Technologies, texts and affordances. Sociology, 35 (2), 44I-456. https://doi.org/I0.II77/S0038038501000219

JORDAN, T. (20I5). Information politics: liberation and exploitation in the digital society. Pluto Press. https://doi.org/I0.2307/j.cttı83p2xf

Kennedy, H., Hill, R. L., Aiello, G., \& Allen, W. (2016). The work that visualisation conventions do. Information, Communication \& Society, I9 (6), 715-735. https://doi.org/I0.I080/I369II8X.20I6.II53I26

KiDD, J. (2016). Representation. Routledge. https://doi.org/I0.4324/9781315666785

Kıм K. (1998). Using GIS technologies to empower community based organizations in Hawaii. Position paper presented at the Project Varenius Specialist Meeting: Empowerment, marginalization, and public participation GIS, Santa Barbara, CA.

Kitchin, R., Perkins, C.\& Dodge, M. (2009). Thinking about maps. Rethinking Maps: New Frontiers in Cartographic Theory, I-25.

Kleine, D., Hollow, D., \& Poveda Villalba, S. C. (2014). Children, ICTs and development: capturing the potential, meeting the challenges. 
Kyem, P.A.K. (200I). Public participation GIS applications and the community empowerment process: A review of concerns and challenges (published 2004). Cartographica, 38 (3\&4), 5-I7. https://doi.org/I0.3I38/2/3I-4648-6P62-6P78

Lee, P.G. \& Global Forest Watch CANADA. (2003). Canada's large intact forest landscapes. Global Forest Watch Canada.

Mesmar, S. , Talhouk, R., Akik, C., Olivier, P., ElhajJ, I. H., Elbassuoni, S., ... \& Ghattas, H. (20I6). The impact of digital technology on health of populations affected by humanitarian crises: recent innovations and current gaps. Journal of Public Health Policy, 37 (2), 167-200. https://doi.org/I0.I057/s4I27I-0I6-0040-I

Mohan, G. (2002). The disappointments of civil society: the politics of NGO intervention in Northern Ghana. Political Geography, 21,125-54. https://doi.org/I0.IOI6/Sog62-6298(OI)00072-5

MOORE, R., BHIDE, N., \& VerITY, A. (20I6). Humanitarian information management failures: survey report. United Nations Office for the Coordination of Humanitarian Affairs, Geneva.

Mosse, D. (200I). People's knowledge', participation and patronage: Operations and representations in rural development. Participation: The New Tyranny, I6-35.

O'HARA, K. (2004). Ontologies and technologies: knowledge representation or misrepresentation. ACM SIGIR Forum, 38, (2), II-I7.

https://doi.org/I0.II45/I04I394.I04I397

Paglen, T. (2008). Mapping Ghosts. In: Mogel, L. and Bhagat, A. (eds.) An atlas of radical cartography. Los Angeles: Journal of Aesthetics and Protest Press, 39-50

PARKER, B. (2006). Constructing community through maps? Power and praxis in community mapping. The Professional Geographer, 58 (4), 470-484. https://doi.org/IO.IIII/j.I467-9272.2006.00583.x

Popping R., \& RoberTs C.W. (1997). Network Approaches in Text Analysis. In Klar R., Opitz O. (eds) Classification and Knowledge Organization. Studies in Classification, Data Analysis, and Knowledge Organization. Berlin, Heidelberg: Springer. https://doi.org/IO.I007/978-3-642-5905I-I_40

PotTs, J. (2015). The new time and space. Palgrave Macmillan. https://doi.org/I0.1057/9781137494382

QuiJAno, A. (2007). Coloniality and modernity/rationality. Cultural Studies, 2I (2-3), I68-I78. https://doi.org/I0.1080/0950238060II64353

RADFORD, T. (20I9) Community Q\&A: Humanitarian OpenStreetMap Team. Interview conducted by Wood, E. for Centre for HumData. Available from:

https://reliefweb.int/report/world/community-qa-humanitarian-openstreetmap-team [Accessed 30 January 2020]

RADIL, S.M. \& JIAO, J. (2016). Public participatory GIS and the geography of inclusion. The Professional Geographer, 68 (2), 202-210. https://doi.org/I0.1080/00330I24.2015.1054750

ReкHA, B. (20I6). Geospatial data: key to achieve SDGs. Geospatial World. Available from : https://www.geospatialworld.net/article/geospatial-data-sustainable-development-goals [Accessed I May 20I7]

SAID, E. W. (1985). Orientalism reconsidered. Race \& class, 27(2), I-I5. https://doi.org/IO.II77/03063968850270020I

SCOTT, G. \& RAJABIFARD, A. (2015). Integrating geospatial information into the 2030 agenda for sustainable development. In: Twentieth United Nations Regional Cartographic Conference for Asia and the Pacific. Jeju, Korea. 6 - 9 October 2015 
SIEBER, R. (2006). Public participation geographic information systems: a literature review and framework. Annals of the Association of American Geographers, 96 (3), 49I-507. https://doi.org/I0.IIII/j.I467-8306.2006.00702.x

SLETTO, B.I. (2009). Indigenous people don't have boundaries: reborderings, fire management, and productions of authenticities in indigenous landscapes. Cultural Geographies, I6 (2), 253-277.

https://doi.org/I0.II77/I474474008101519

Specht, D. \& Feigenbaum, A. (20I8). From cartographic gaze to contestatory cartographies. In: Pol Bargués-Pedreny, P., Chandler, D. and Simon, E. (eds.) Mapping and politics in the digital age. Routledge Global Cooperation Series, 39-55. https://doi.org/I0.4324/9781351124485-3

Verplanke, J., McCall, M. K., Uberhuaga, C., Rambaldi, G., \& Haklay, M. (20i6). A shared perspective for PGIS and VGI. The Cartographic Journal, 53 (4), 308-317. https://doi.org/I0.1080/0008704I.2016.1227552

WAINWRIGHT, J. \& BRYAN, J. (2009). Cartography, territory, property: postcolonial reflections on indigenous counter-mapping in Nicaragua and Belize. Cultural Geographies, I6 (2), I53-I78. https://doi.org/I0.II77/I47447400810I515 



\section{4

\section{Presentación · Foreword}

\section{Artículos · Articles}

19 Eugenio Climent López y Samuel Esteban Rodríguez

La crisis económica de 2008 en las Denominaciones de Origen Protegidas de vino españolas: efectos y modelos de salida. The 2008 Economic Crisis in the Spanish Protected Designations of Origin of Wine: Effects and Exit Models

4.5 David García-Reyes, EnRICo Marini y Marta Gallardo

Infancia, pobreza y deporte en el desierto de Calama, Chile. Representaciones sociales en «Segundo tiempo, último gol gana» . Childhood, Poverty and Sport in the Desert of Calama, Chile. Social Representations in «Segundo tiempo, último gol gana»

José Antonio González díaz, Benjamín González díaz y Rocío Rosa GARCía

Revisión de los objetivos de los espacios protegidos: el parque natural y reserva de la biosfera de Redes - Review of the Objectives of Protected Spaces: Natural Park and Biosphere Reserve of Redes

Álvaro-Francisco Morote Seguido

Investigación y enseñanza en didáctica de la climatología. Estado de la cuestión (1980-2020) (España) · Research and Teaching in Didactic of Climatology. State of the Art (1980-2020) (Spain)

\section{Gemma Ruiz Ángel y Mariano Cecilia Espinosa}

Rogativas pro - pluvia en la catedral de Orihuela: La sequía en Orihuela durante el siglo XVII · Rogative Pro - Pluvia in the Cathedral of Orihuela: The Drought in Orihuela during the $17^{\text {th }}$ Century

\section{5}

José Ramón Sánchez Holgado

La puesta en valor de los campos de concentración y exterminio nazis como lugar de memoria . Putting Value of the Nazis Extermination and Concentration Camps as a Place of Memory

\section{7}

LAURA Sevilla CuAdrado

La conciencia medio ambiental en el sector del turismo de sol y playa. Un estudio con la técnica Delphi . Environmental Awareness in the Sun, Sea and Sand Tourism Sector. A Study using the Delphi Technique

The Technopolitics of Mapping Dar es Salaam: An Examination of the Technological and Political Motivations of the Humanitarian OpenStreetMap Team La tecnopolítica de la cartografía de Dar es Salaam: Un examen de las motivaciones tecnológicas y políticas del equipo humanitario OpenStreetMap

\section{Reseñas · Book Review}

19 De LÁzaro Torres, María Luisa y Morales Yago, Francisco José (2021). Introducción a la Investigación en Geografía. Pautas para la Elaboración de Trabajos Científicos (An Introduction to Research in Geography. Guidelines for the Preparation of Scientific Papers). UNED, 223 Pp., ISBN: 978-84-362-7689-3. (JuLIO FERNÁNDEZ PORTELA

Fernández Portela, Julio y Hernández García, Ricardo (2021). Sociedad y territorio en Cubillas de Santa Marta: del Catastro de Ensenada a la actualidad. Ayuntamiento de Cubillas de Santa Marta, 259 pp., ISBN: 978-84-09-28428-3. (MIGUEL ÁngEL GarCía VELASCO)

MÉndez GutiérRez del VALLe, R. (2020). Sitiados por la pandemia. Del colapso a la reconstrucción: apuntes geográficos. Revives, 183 pp. (ROSA MECHA

23 MARTín-Roda, Eva María (2021). Geopolítica de los recursos energéticos. Síntesis, 276 pp., ISBN: 9788413571348 ; ISBN Digital: 9788413576626 (AURELIO NiETO CODINA)

235 Moreno BorrelL, S. (2019). La Naturaleza y el Paisaje de Málaga a través de viajeros, naturalistas y científicos. La Serranía, 224 Pp., ISBN: 978-8415588-28-3 (SERGIO REYES CORREDERA)

\section{Imágenes y palabras · Pictures and Words}

\subsection{JULıo López-DavaliLlo LARREA \\ La laguna de Herramélluri. Un humedal renacido . The Herramélluri Lagoon.}

\section{Síntesis de Tesis Doctorales · Summaries of Doctoral Thesis}

\section{Javier Álvarez Otero}

El uso educativo de las Infraestructuras de Datos Espaciales (IDE) para mejorar la responsabilidad social de los ciudadanos del siglo XXI sobre el territorio. Departamento de Didáctica de las Ciencias Experimentales, Sociales y Matemáticas. Universidad Complutense de Madrid. Directora: Dra. Doña María Luisa de Lázaro Torres. Fecha: 10 de diciembre de 2020

\section{José Fernández Álvarez}

Dinámica evolutiva de los usos y coberturas del suelo en la provincia de Salamanca. Análisis comparado y repercusiones en el paisaje rural de cuatro comarcas de estudio. Departamento de Geografía, Universidad Nacional de Educación a Distancia (UNED). Director: Dr. D. Carlos Javier Pardo Abad. Fecha: 27 de mayo de 2021 